without any particular system, sometimes merely for the purpose of justifying lines. But in general the type is well made and the press work good. When two German printers, Conrad Sweynheym and Arnold Pannartz, set up the first press in Italy, under the patronage of the abbot of the Benedictine monastery at Subiaco, type was cast in the solid and angular Gothic forms. In Italy another form of letter, smoother and rounder and less massive, modelled on the script which was in use in humanistic circles, developed, which later came to be used for all ordinary printing. This book which has come to the Society is a fine example of the "roman" type. The book is very rare. There is only one other copy known to be in the United States.

\title{
A Tragedy and a Rescue
}

ONE of the primary purposes of the founders of The Business Historical Society was to effect the preservation of valuable historical documents and records which, for one reason or another, are so often destroyed by their owners. Not always, however, is the Society able to do so.

An amusing and at the same time heartbreaking instance came to its attention recently where an old Maine farmhouse had been subjected to a housecleaning, and where the owners reported they had found many letters signed by Abraham Lincoln. Supposing that the signatures might be of value, they clipped out all the signatures and burned the letters.

Another lost opportunity was revealed about a year ago when news was received of the sale for waste paper and subsequent destruction of about twenty-three tons of government Custom House records at the port of Philadelphia, antedating the year 1789 . At that time the Pennsylvania Historical Society stored in their basement as much of this material as was, from their point of view, of any consequence. The rest, containing perhaps much that would have been valuable from the standpoint of our collection, was irretrievably lost.

Quite by chance, information was recently received that the Philadelphia Collector of Customs was again advertising for bids on approximately 80,000 pounds of old Custom House records. These bids were to be on the basis of so much a hundred pounds of paper, and removal of forty odd tons was to be effected within forty-eight hours. 
As only two or three days remained, the Society immediately began a campaign by telephone and telegraph, communicating with the Department of Commerce, Congressmen and friends, and particularly with the Library of Congress and the Chairman of the Congressional Committee on the Disposal of Waste Paper. The Society took the position that such a sale was illegal under an executive order issued by President Taft, but that if it could not be prevented, the Society desired to enter its bid and provide for the preservation of the material. Exactly what could be done with some forty tons of old papers remained somewhat problematical. Fortunately, however, a telegram was received the day before the sale of the papers that the Library of Congress and the Customs Division, with the assistance of other government departments, had stopped the proceedings and were actively considering the best method for their preservation. An extract from a letter received from the Chief of the Manuscript Department of the Library of Congress will perhaps tell its own story and indicate that this action on the part of the Society may have accomplished more than the saving of this particular lot of documents.

"I believe that the representations on behalf of the Library to the Commissioner of Customs here," he writes, "have checked any similar movements toward destruction in other parts. It appears that the collector at Philadelphia, and I presume that the same is true of other collectors, was not aware of the executive order. . .

We are all greatly obliged to the officers of The Business Historical Society for calling our attention to the proposed sale and probable destruction of papers."

\section{The Oldest Joint-Stock Company}

WE ARE indebted to Mr. E. A. S. Clarke, Secretary of the American Iron and Steel Institute, for calling our attention to an article in the IgOI Transactions of the British Institute which places the oldest joint-stock enterprise in the world at Domnarfvet, Sweden. It is the Stora Kopparbergs (Great Copper Mountain) Mining Company, deriving its name from the celebrated copper mine at Falun, where one of its plants is located.

In I896, the Company celebrated its 550 th anniversary, dating from its oldest charter; and a deed for the transfer of shares in the Company dated 1288 is still in existence in the State archives. Its 